\title{
Nurses And Community Health Workers'awareness And Practices Regarding Child And Adolescent Mental Health In Ekiti State, Nigeria
}

\author{
*Elizabeth O. Akinyemi, **Adedeji J. Ogunleye, **Samuel O. Olatunji \\ *Yetunde C. Adeniyi, and $* * *$ Benjamin.O Omolayo \\ * Centre for Child and Adolescent Mental Health, University Teaching Hospital, University of Ibadan. \\ **Department of Psychology and Behavioural Studies, Ekiti State University, Ado Ekiti; Nigeria \\ ***Department of Psychology, Federal University, Oye Ekiti
}

\begin{abstract}
This study was designed to assess the levels of awareness and practises regarding Child and Adolescent Mental Healthcare (CAMH) among the Primary Healthcare Providers (PHP) in Ekiti State, Nigeria. A hospital based cross-sectional study was conducted using a three-stage sampling technique. A total of 371 (191 nurses and 180 community health workers) respondents were randomly selected from ten (10) primary health care centres in two local government areas selected for the study. The respondents' age ranged from 18 to 56 years (mean age $=35.7$ years). Information was collected using a self- administered semi-structured questionnaire. Results of data analyses indicated that about half of the primary healthcare workers have worked for a period of 1-5 years in primary health care centres. Most of the PHP said they first heard of CAMH from school, while about $32 \%$ of them claimed to first hear about CAMH from home. A high proportion (73.5\%) of the PHPs said they have limited confidence in themselves to recognize when a child or adolescent has a mental illness. The awareness of CAMH among the PHPs did not translate to actual full involvement in good practice regarding CAMH services, and the levels of practices are worse among the community health workers. Advocacy and training opportunities are needed to address the problem. Specifically, regular training programmes to address specific needs such as prompt referral and correct treatment for children and adolescents with mental health problems are recommended.
\end{abstract}

Keywords: Child and Adolescent Mental Health, Primary Healthcare Providers, Awareness and Practices, Nigeria.

\section{Introduction}

The place of good mental health status in normal day functioning of children, adolescents, and adults alike has been documented in literature. According to the World Health Organization (WHO, 2014), mental health can be defined as a state of well-being in which every individual realises his or her own potential, can cope with the normal stresses of life, can work productively and fruitfully, and is able to make a contribution to her or his community. Thus, mental health disorder refers to any condition that affects the mood, thinking and behaviour of people. Mental health disorders account for about $15-30 \%$ of the disability-adjusted life year (DALYs) lost in the first three decades of life (Kieling, 2010). It has been shown that mental illness inflicts a significant burden on individuals, their families and the society (Kalian, 2010; Zechmeister, 2008). Healthcare is the responsibility of the three tiers of government in Nigeria. The first and lowest tier of government is the local government which is majorly responsible for the delivery of primary healthcare. Thus, local government areas employ primary healthcare providers as first line of contact in health and related issues to the community including children and adolescents; and act as a principal point of continuation of care within the healthcare system. In Nigeria, and in most developing countries, the primary healthcare facilities are the first place of seeking for health, partly because of its nearness and accessibility to individuals and families in a community than are the secondary and tertiary healthcare facilities (Patel, Flisher, Nikapota, \& Malhotra, 2008). Therefore, the primary healthcare providers play significant roles in providing "essential healthcare" to people in various communities, including some mental health-related cares. The primary healthcare providers attend to approximately all health and related issues in the developing countries (Eaton et al., 2011), and in Nigeria, these categories of health workers play important role in delivering healthcare services, and most importantly, mental health care, to the community. Thus a good understanding of the awareness and practice of primary healthcare providers relating to child and adolescent mental health is necessary for the purpose of finding solution to the challenges of mental health care services. 
It is established that $12-20 \%$ of children seen in primary healthcare settings are confronted with substantial psychosocial problems, which are induced by mental health problems (Wolraich et al., 1996). Research findings also suggest that the cost for primary healthcare of children who have psychosocial symptoms far exceed the average patients' cost (Bernal et al, 2000). However, primary healthcare providers, who constitute the first in the line of health provision, appear not to be adequately empowered to address mental health challenges in Nigeria (Adewuya et al., 2007). There seem to be obvious barriers to provision of mental healthcare to children and adolescents at the primary health facilities in most parts of Nigeria (Adewuya et al., 2007). Anecdotal evidences suggest that there is dearth of baseline data on the existing practices of these health workers. This information is essential for planning effective and sustainable interventions directed towards improving the healthcare workers practises and behaviour towards mental health care in children and adolescents. According to Hinshaw et al.(2005), there is a plethora of researches relating to mental health stigmatization, focusing on the general population as the source and also on the consequences of stigma for patients and their families who provide care. Not much importance seems to have been placed on the people who are entrusted with the duties of providing care for the people with mental disorders. It is therefore expedient to generate data that can form the basis for designing programmes and interventions geared towards improving attitude and practices of key personnel in the primary healthcare sector in Nigeria. This study is, therefore, poised to describe the level of awareness and current practices of nurses and community health workers regarding the care of children and adolescents with mental health illnesses.A review of the register of the primary healthcare providers in the study area revealed that there are only four doctors playing supervisory roles while nurses and the community health workers constitute the main workforce providing care for patients at the primary health centres. Hence, the reason for focussing this research on the nurses and community health workers.

\section{Methods}

Participants: This study is a hospital based cross sectional study involving the use of semi-structured questionnaire interviewing the PHCPs at primary healthcare facilities in two selected local government areas in Ekiti State, Nigeria. The study population comprised of primary healthcare providers practicing within the local government areas selected. Primary healthcare workers who do not provide direct care and treatment (Laboratory attendants, X-ray technicians and workers at the health records) were not included. Thus, a sample of 371 research participants (191 nurses and 180 community health workers) was randomly selected. The respondents' age ranged from 18 to 56 years (mean age $=35.7$ years). Sampling method used in this study was the multi-stage random sampling to select local government areas, primary healthcare facilities, and sample participants for the study.

Measures:

A self-administered questionnaire with items adapted from those used by Adewuya and Oguntade (2007) and Ani et al (2011) was used for data collection. The questionnaire contained 3 main sections with open and closed-ended questions, namely;

A. Socio-demographic characteristics

B. Awareness of child and adolescent mental health inventory

C. Healthcare providers practices in relation to child and adolescent inventory.

Procedure:

The administration of the questionnaire was coordinated and monitored by the researchers, assisted by trained postgraduate students from the Ekiti State University. Approval for the study was obtained from the Ekiti State Ministry of Health Ethical Review Committee. Participation in the study was completely voluntary and informed consent was obtained from each eligible respondent. Respondents were informed of their freedom to withdraw at any time.

Method of Data Analysis: The data were entered and analysed using the statistical package for social sciences (SPSS Inc., Chicago USA) Version 20.0. Chi-square was used to test associations between two or more categorical variables. The level of significance was set at $\mathrm{p}=0.05$. 


\section{Results}

Figure 1: Distribution of the respondents by age groups.

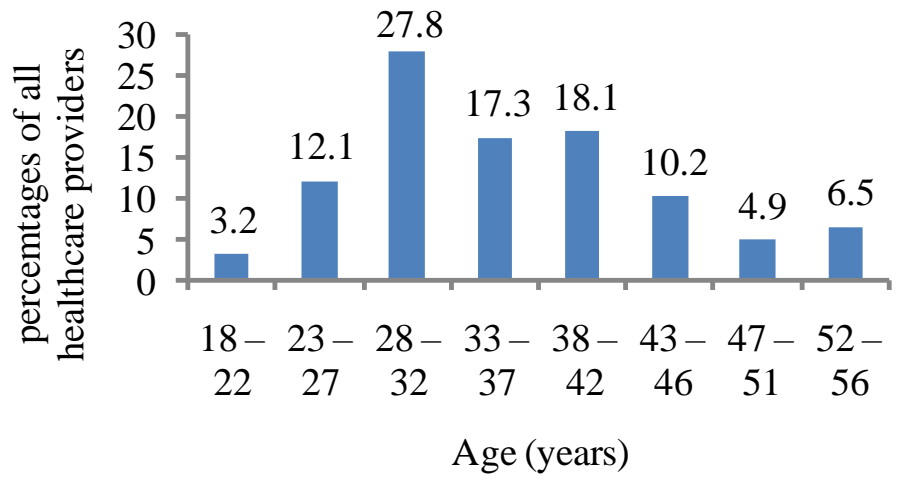

Table 1: Socio-Demographics Characteristics of Respondents

\begin{tabular}{|c|c|c|c|c|c|c|c|}
\hline \multirow{2}{*}{$\begin{array}{l}\text { Demographics } \\
\text { Variables }\end{array}$} & \multicolumn{2}{|c|}{$\begin{array}{l}\text { Nurses } \\
(\mathrm{N}=191)\end{array}$} & \multicolumn{2}{|c|}{$\begin{array}{c}\text { CHW } \\
(\mathrm{N}=180)\end{array}$} & \multicolumn{2}{|c|}{$\begin{array}{c}\text { Total } \\
(\mathbf{N}=\mathbf{3 7 1})\end{array}$} & \multirow[t]{2}{*}{$\mathbf{P}$} \\
\hline & $\mathbf{n}$ & $\%$ & n & $\%$ & $\mathbf{n}$ & $\%$ & \\
\hline \multicolumn{8}{|l|}{ Gender } \\
\hline Male & 35 & 39.3 & 54 & 60.7 & 89 & 100 & 0.008 \\
\hline Female & 156 & 55.3 & 126 & 44.7 & 282 & 100 & \\
\hline \multicolumn{8}{|l|}{ Religion } \\
\hline Christianity & 147 & 51.2 & 140 & 48.8 & 287 & 100 & 0.851 \\
\hline Islam & 44 & 52.4 & 40 & 47.6 & 84 & 100 & \\
\hline \multicolumn{8}{|l|}{ Marital status } \\
\hline Single & 18 & 22.2 & 63 & 77.8 & 81 & 100 & 0.001 \\
\hline Married & 164 & 58.4 & 117 & 41.6 & 281 & 100 & \\
\hline Separated & 9 & 10.4 & 0 & 0 & 9 & 100 & \\
\hline \multicolumn{8}{|l|}{ Educational level } \\
\hline Post graduate & 1 & 100 & 0 & 0 & 1 & 100 & 0.001 \\
\hline University & 54 & 93.1 & 4 & 6.9 & 58 & 100 & \\
\hline Nursing school & 110 & 85.3 & 19 & 14.7 & 129 & 100 & \\
\hline $\begin{array}{l}\text { Health } \\
\text { technology }\end{array}$ & 26 & 14.2 & 157 & 85.8 & 183 & 100 & \\
\hline
\end{tabular}

Figure 2: Distribution of Healthcare Providers by Duration of Practice 


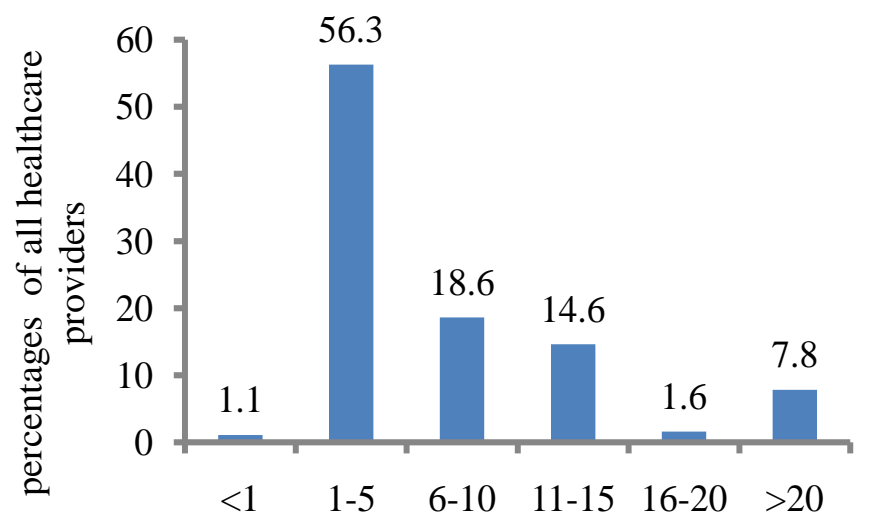

Duration of Practice (years)

Figure 3. Awareness of Primary Healthcare Providers about Child and Adolescent Mental Health

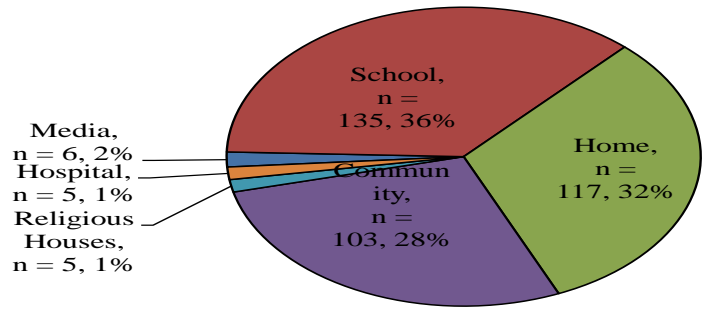

Table 2: Distributions of Respondents by their Awareness of Different Types of Mental Health Disorders in Children and Adolescents

\begin{tabular}{|c|c|c|c|c|c|c|c|c|c|c|c|c|c|}
\hline \multirow[t]{3}{*}{ Mental health problems } & \multicolumn{4}{|c|}{$\begin{array}{c}\text { Nurses } \\
(\mathrm{N}=191)\end{array}$} & \multicolumn{4}{|c|}{$\begin{array}{c}\text { CHW } \\
(\mathrm{N}=180)\end{array}$} & \multicolumn{4}{|c|}{$\begin{array}{c}\text { Total } \\
(\mathbf{N}=371)\end{array}$} & \multirow[t]{3}{*}{$\mathrm{P}$} \\
\hline & \multicolumn{2}{|c|}{ Yes } & \multicolumn{2}{|c|}{ No } & \multicolumn{2}{|c|}{ Yes } & \multicolumn{2}{|c|}{ No } & \multicolumn{2}{|c|}{ Yes } & \multicolumn{2}{|c|}{$\mathrm{N}_{0}$} & \\
\hline & $\mathbf{N}$ & $\%$ & $\mathbf{N}$ & $\%$ & $\mathbf{N}$ & $\%$ & $\mathbf{n}$ & $\%$ & $\mathbf{N}$ & $\%$ & $\mathbf{N}$ & $\%$ & \\
\hline Conduct disorders & 113 & 59.2 & 78 & 40.8 & 24 & 13.3 & 156 & 86.7 & 137 & 36.9 & 234 & 63.1 & 0.001 \\
\hline Attention deficit hyperactivity disorders & 72 & 37.7 & 119 & 62.3 & 17 & 9.4 & 163 & 90.6 & 89 & 24.0 & 382 & 76.0 & 0.001 \\
\hline Autism & 173 & 90.6 & 18 & 9.4 & 81 & 45.0 & 99 & 55.0 & 254 & 68.5 & 117 & 31.5 & 0.001 \\
\hline Anxiety & 143 & 74.9 & 48 & 25.1 & 55 & 30.6 & 125 & 69.4 & 198 & 53.4 & 173 & 46.6 & 0.001 \\
\hline Phobia & 154 & 80.6 & 37 & 19.4 & 97 & 53.9 & 83 & 46.1 & 251 & 67.7 & 120 & 32.3 & 0.001 \\
\hline Schizophrenia & 68 & 35.6 & 123 & 64.4 & 15 & 8.3 & 165 & 91.7 & 83 & 22.4 & 288 & 77.6 & 0.001 \\
\hline Bipolar disorder & 63 & 33.2 & 127 & 66.8 & 10 & 5.6 & 170 & 94.4 & 73 & 19.7 & 297 & 80.3 & 0.001 \\
\hline Depression & 189 & 99.0 & 2 & 1.0 & 155 & 86.1 & 25 & 13.9 & 344 & 92.7 & 27 & 7.3 & 0.001 \\
\hline Post-traumatic stress disorders & 131 & 68.6 & 60 & 31.4 & 60 & 33.3 & 120 & 66.7 & 191 & 51.5 & 180 & 48.5 & 0.001 \\
\hline Drug addiction & 189 & 99.0 & 2 & 1.0 & 179 & 99.4 & 1 & .6 & 368 & 99.2 & 3 & .8 & 0.597 \\
\hline Eating disorders & 159 & 83.2 & 32 & 16.8 & 72 & 40.0 & 108 & 60.0 & 231 & 62.3 & 140 & 37.7 & 0.001 \\
\hline Attachment disorder & 103 & 54.5 & 17 & 9.4 & 17 & 9.4 & 163 & 90.6 & 120 & 32.5 & 249 & 67.5 & 0.001 \\
\hline
\end{tabular}


Table 3: Frequency Distributions of Respondents Practices on Child and Adolescent Mental Health

\begin{tabular}{|c|c|c|c|c|c|c|c|c|c|c|c|c|c|}
\hline \multirow[t]{3}{*}{$\begin{array}{l}\text { Questions on practices relating to child and } \\
\text { adolescent mental health. }\end{array}$} & \multicolumn{4}{|c|}{$\begin{array}{c}\text { Nurses } \\
(\mathrm{N}=191)\end{array}$} & \multicolumn{4}{|c|}{$\begin{array}{c}\text { CHWs } \\
(\mathrm{N}=180)\end{array}$} & \multicolumn{4}{|c|}{$\begin{array}{c}\text { Total } \\
(\mathrm{N}=371) \\
\end{array}$} & \multirow[t]{3}{*}{$P$} \\
\hline & \multicolumn{2}{|c|}{ Yes } & \multicolumn{2}{|c|}{ No } & \multicolumn{2}{|c|}{ Yes } & \multicolumn{2}{|c|}{ No } & \multicolumn{2}{|c|}{ Yes } & \multicolumn{2}{|c|}{ No } & \\
\hline & $\mathrm{N}$ & $\%$ & $\mathbf{N}$ & $\%$ & $\mathrm{n}$ & $\%$ & $\mathbf{n}$ & $\%$ & $\mathbf{n}$ & $\%$ & $\mathrm{n}$ & $\%$ & \\
\hline $\begin{array}{l}\text { Have you ever received training on providing mental } \\
\text { health education? }\end{array}$ & 138 & 72.3 & 53 & 29.4 & 53 & 27.7 & 127 & 70.6 & 191 & 100 & 180 & 100 & 0.001 \\
\hline Is providing health education part of your duty? & 191 & 51.6 & 0 & 0 & 179 & 48.4 & 1 & 100 & 1 & 100 & 370 & 100 & 0.302 \\
\hline $\begin{array}{l}\text { Have you ever received training on child and } \\
\text { adolescent mental health? }\end{array}$ & 9 & 100 & 182 & 50.3 & 0 & 100 & 180 & 49.7 & 9 & 100 & 362 & 100 & 0.002 \\
\hline $\begin{array}{l}\text { Have you ever seen a child or adolescent in your climic } \\
\text { that appears to have a mental illness? }\end{array}$ & 104 & 74.8 & 87 & 37.5 & 35 & 25.2 & 145 & 62.5 & 139 & 100 & 232 & 100 & 0.001 \\
\hline $\begin{array}{l}\text { Do you know of any hospital that takes care of } \\
\text { children? }\end{array}$ & 117 & 75.5 & 74 & 34.3 & 38 & 24.5 & 142 & 65.7 & 155 & 100 & 216 & 100 & 0.001 \\
\hline $\begin{array}{l}\text { Do you know of any medication that can be used to } \\
\text { treat children with mental illness? }\end{array}$ & 12 & 85.7 & 179 & 50.1 & 2 & 14.3 & 178 & 49.9 & 14 & 100 & 357 & 100 & 0.009 \\
\hline $\begin{array}{l}\text { If you come across a child or adolescent in your climic } \\
\text { who is tearful and feeling very sad and depressed, } \\
\text { would you know how to assist the child to get help? }\end{array}$ & 133 & 71.5 & 58 & 31.4 & 53 & 28.5 & 127 & 68.6 & 186 & 100 & 185 & 100 & 0.001 \\
\hline $\begin{array}{l}\text { If you saw a child in your centre who is talking about } \\
\text { killing himselfherself, would you know what to do to } \\
\text { assist the child to get help? }\end{array}$ & 115 & 73.7 & 76 & 35.3 & 41 & 26.3 & 139 & 64.7 & 156 & 100 & 215 & 100 & 0.001 \\
\hline
\end{tabular}

Table 4: Respondents' Responses to their Confidence to Practice Child and Adolescent Mental Health

\begin{tabular}{|c|c|c|c|c|c|c|c|c|c|c|c|c|c|c|c|c|c|c|c|}
\hline \multirow{3}{*}{$\begin{array}{l}\text { Primary healthcare } \\
\text { providers' confidence in } \\
\text { practicing child and } \\
\text { adolescent mental health. }\end{array}$} & \multicolumn{6}{|c|}{$\begin{array}{c}\text { Nurses } \\
(\mathbf{N}=191)\end{array}$} & \multicolumn{6}{|c|}{$\begin{array}{c}\text { CHWs } \\
(\mathrm{N}=180)\end{array}$} & \multicolumn{6}{|c|}{$\begin{array}{c}\text { Total } \\
(\mathbf{N}=371)\end{array}$} & \multirow{3}{*}{ p } \\
\hline & \multicolumn{2}{|c|}{$\begin{array}{l}\text { Very } \\
\text { good }\end{array}$} & \multicolumn{2}{|c|}{ Good } & \multicolumn{2}{|c|}{ Limited } & \multicolumn{2}{|c|}{$\begin{array}{l}\text { Very } \\
\text { good }\end{array}$} & \multicolumn{2}{|c|}{ Good } & \multicolumn{2}{|c|}{ Limited } & \multicolumn{2}{|c|}{$\begin{array}{l}\text { Very } \\
\text { good }\end{array}$} & \multicolumn{2}{|c|}{ Good } & \multicolumn{2}{|c|}{ Limited } & \\
\hline & n & $\%$ & $\mathbf{n}$ & $\%$ & $\mathbf{n}$ & $\%$ & n & $\%$ & $\mathbf{n}$ & $\%$ & $\mathbf{n}$ & $\%$ & . & $\%$ & $\mathbf{n}$ & $\%$ & $\mathbf{n}$ & $\%$ & \\
\hline $\begin{array}{l}\text { How would you rate your } \\
\text { confidence in recognizing } \\
\text { when a child and } \\
\text { adolescent has mental } \\
\text { illness }\end{array}$ & 2 & 100 & 69 & 70.4 & 120 & 44.3 & 0 & 0 & 29 & 29.6 & 151 & 55. & 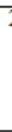 & 100 & 96 & 100 & 271 & 100 & 0.001 \\
\hline $\begin{array}{l}\text { Over all how would you } \\
\text { rate your confidence in } \\
\text { being able to help a child } \\
\text { or adolescent who has } \\
\text { mental illness }\end{array}$ & 4 & 100 & 90 & 73.2 & 97 & 39.8 & 0 & 0 & 33 & 26.8 & 147 & 60. & 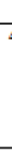 & 100 & 23 & 100 & 244 & 100 & 0.001 \\
\hline $\begin{array}{l}\text { Over all do you believe all } \\
\text { primary healthcare } \\
\text { providers have a } \\
\text { responsibility to identify } \\
\text { and, or, treat child or } \\
\text { adolescent with mental } \\
\text { illness to the best of their } \\
\text { ability }\end{array}$ & 3 & 75.0 & 76 & 71.0 & 112 & 43 & 1 & 25.0 & 31 & 29.0 & 148 & 56. & 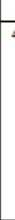 & 100 & 107 & 100 & 260 & 100 & 0.001 \\
\hline
\end{tabular}

Table 5: Respondents' forms of assistances to children or adolescents with suicidal ideation $n=151(40.80 \%)$ of the total population of $n=371(100 \%)$

\begin{tabular}{|l|l|l|}
\hline Primary healthcare providers' Practices to help a child with suicidal ideation. & n & \% \\
\hline & & \\
\hline No response & 220 & 59.2 \\
\hline Counseling & 9 & 2.4 \\
\hline Advice parents to seek spiritual help (deliverance/prayer/traditional medicine) & 16 & 4.4 \\
\hline Refer (psychiatrist/psychologist/general and teaching hospitals) & 126 & 34.0 \\
\hline Total & 371 & 100 \\
\hline
\end{tabular}


Table 6: Respondents Suggested Medications used In the Treatment of Mental Illness in Children and Adolescents

$\{n=13(3.5 \%)$ of the total population of $n=371(100 \%)$ have an idea of drugs to be used in mental illnesses treatment\}

\begin{tabular}{|l|l|l|}
\hline $\begin{array}{l}\text { Primary health care providers known medication that can be used to } \\
\text { treat children with mental illness? }\end{array}$ & $\mathrm{n}$ & $\%$ \\
\hline & & \\
\hline No response & 358 & 96.5 \\
\hline Amitriptyline & 1 & 0.3 \\
\hline Antidepressant & 3 & 0.7 \\
\hline Carbamazepine & 1 & 0.3 \\
\hline Haldol & 1 & 0.3 \\
\hline Largactil & 5 & 1.3 \\
\hline Risperidone & 1 & 0.3 \\
\hline Tegretol & 1 & 0.3 \\
\hline Total & 371 & 100.0 \\
\hline
\end{tabular}

\section{DISCUSSION}

This study revealed that most of the primary health care providers have heard of child and adolescent mental health $(\mathrm{CAMH})$ either from school or from home. Also A high proportion of the primary health care providers had relatively high awareness about major mental health conditions in children and adolescents. These findings are in consonance with findings from previous studies. For example, a qualitative study that was done among primary health care professionals' perception of mental health among young people in Nicaragua found that most of the professionals had adequate information on mental illness among young people (Medina et al, 2014). Other studies have reported similar findings (Urada et al, 2012; Kapungwe et al, 2011; Winer et al, 2013). In comparing the nurses and the community health workers in the present study however, results revealed that the nurses were more aware of signs of mental illness in children and adolescents than the community health workers. This might be due to the clinical exposure and experiences the nurses had during their training in the nursing school.Almost all the respondents agreed that the provision of health education is part of their duty. Nonetheless, majority of the respondents answered no to having ever received training on child and adolescent mental health. With regards to clinical practice, less than half of the respondents said YES to "If you come across a child or adolescent in your clinic that is tearful and feeling very sad and depressed, would you know how to assist the child to get help? Of those who said yes, majority of them stated that they will counsel or refer the child. In response to the practice question "If you saw a child in your centre who is talking about killing himself/herself, would you know what to do to assist the child to get help?", one third of the respondent said 'yes'. Of those who said 'yes', a good number of the respondents stated that they will refer to a psychiatrist/psychologist, refer to a psychiatric hospital, followed by advising parents of the child to seek for spiritual help.However, majority of the primary health care providers said they had limited confidence in themselves to recognize when a child or adolescent has a mental illness. Few of the respondents had confidence in their ability to help a child or adolescent with mental illness. Only (9) of the nurses said they have had training on child and adolescent mental health while none of the community health workers have had such training. To the question, "have you ever seen a child or adolescent in your clinic that appears to have a mental illness?" Half of nurses/midwives said yes. However most of the community health workers said no. A lot of children and adolescents would have passed through these primary healthcare providers without been recognized following the established fact that 1 in 5 children have a recognizable treatable mental health problem. More than half the nurses seem to know the hospitals that take care of children with mental illness compare to majority of the community health workers who do not. This shows the importance of providing training and exposure to primary healthcare providers on child and adolescent mental health given that they may come across children with more serious mental health problems irrespective of their actual clinical roles. This finding partly agrees with another study that reported that higher cadres of professionals between the ages of 40 years and above felt the responsibility of caring for the individual with mental illness as compared with individuals of lower cadres whose proportion decreased with age (Ndetei, et al 2011). The lower cadres could be said to be under trained on mental health related issues. In a study conducted among primary health care providers in Idaho, it shows that these primary care providers are highly utilized yet majority of them are either undertrained or not trained at all and as such are lacking in their ability to identify and treat mental health and related problems and or misdiagnose these problems in their patients (Theiler, 2011).Findings from this study 
about the primary healthcare provider practices shows that at the moment, no known national or state guidelines exist on child and adolescent mental health services in the Ekiti State. More studies are needed on what should constitute the content and mode of delivery of child and adolescent mental health in the state. In addition there is need to send primary healthcare providers for in-service training that focuses on CAMH and encourage more teachings on $\mathrm{CAMH}$ services at nursing schools and at the health technology school where the primary healthcare workers are being trained

\section{CONCLUSION}

The findings from this study showed that child and adolescent mental health care / services are not routinely offered by majority of the nurses and community health workers working at the primary healthcare centres in Ekiti state. Despite the awareness level of mental illness among the primary healthcare providers especially the nurses, it did not translate to actual full involvement and correct practices of CAMH services. The primary healthcare providers reported to have no/little training in CAMH.Therefore there is a need for intervention in training the primary healthcare providers to improve good practices and good awareness programs.

\section{LIMITATIONS OF THE STUDY}

Limitation of this study is that the participants were limited to the nurses and community health workers working at the primary health centres primary in two local government areas out of the 16 local governments in Ekiti state. Also the data might not completely represent the actual situation of all health workers in the state.

\section{RECOMMENDATIONS}

Based on the findings from this study, the followings are recommended:

1. Inclusion of courses on CAMH in nursing training curriculum and the health technology colleges.

2. Organisation of refresher courses on CAMH for the primary healthcare providers (nurses and community health workers) in Ekiti state.

3. Provision of guidelines for carrying out Child and Adolescent Mental Health at the various health facilities in Ekiti State.

4. There is need to encourage the PHP to improve on their health information seeking habits through the internet and journals.

5. Development of a National Policy on Child and Adolescent Mental Health.

6. Further studies on training needed, acceptability, advocacy and impacts of CAMH in the health facilities in Ekiti state.

\section{REFERENCES}

[1] Abiodun O. A. (1992). Emotional illness in a pediatric population in Nigeria.East Afr Med J 10: 557-559.

[2] Adewuya, A., Efinfolami A.R., Ola B.A., (2011). Correlates of self-stigma among out-patients with mental Illness in Lagos, Nigeria.Int. j. social psychiatry, 57: 418-227.

[3] Adewuya A. O., Oguntade, A.A., (2007). Doctors' Attitude towards people with mental illness in western Nigeria.SocPsychiatriEpidemiol 42: 931-936.

[4] Akerele, D., Adewuyi, S. A. (2011) "Analysis of Poverty Profiles and Socioeconomic Determinants of Welfare among Urban Households of Ekiti State, Nigeria" Current Research Journal of Social Sciences 3(1): 1-7

[5] Bernal P., Estroff, D., Aboudarham, J. (2000). Psychosocial Morbidity: The economic burden in a pediatric health maintenance organization sample. Archives of Pediatrics\& Adolescent Medicine 154: 261-266.

[6] Brauner, C., Stephens, CB., (2006). Estimating the prevalence of early childhood serious emotional/behavioral disorders: challenges and recommendations.121: 303-310.

[7] Bruckner T., Scheffler, RM., Shen, G., Yoon, J., Chisholm, D., Morris, J., Fulton, BD., Dal Poz, MR., Saxena, S. (2011). The mental health workforce gap in low- and middle-income countries: a needs-based approach. Bull World Health Organ 89: 184-194.

[8] Burns B., et al., (2004). Mental health need and access to mental health service by youths Involved with child welfare.J.AmAcad child Adolescpsychiatr 43: 960-970.

[9] Cortina M. A., Shodha, A., Fazel, M., Ramchandani, P.G. (2012). Prevalence of child mental health problems in sub-Saharan Africa: a systematic review. Arch pediatrAdolesc Med 166: 276-281.

[10] Costello E., Mustillo, S., Keller G., Angold, A. (2004). Prevalence of psychiatric disorders in childhood and adolescence In: Levin BL, Petrila J, And Hennessy KD, eds. Mental Health Services: a Public Health Perspective. Second Edition. Oxford, UK: Oxford University Press: 111-128. 
[11] David, M., Matins, K., Sohba, R, (2008). Barriers in the mind: promoting an economic case for mental health in low- and middle-income countries. Journal of the world psychiatry 7 79-86.

[12] Eaton, J., McCay, L., Semrau, M., Chatterjee, S., Baingana, F., Araya, R. (2011). Scale up of services for mental health in low-income and middle-income countries. . Lancet 14: 3-12.

[13] Fayyad J. A., Jahshan, C.S., and Karam, E.G. (2001).Systems development of child mental service in developing countries.Child AdolescPsychiarClin North Am 10: 745-762.

[14] Flisher A., Kramer, R.A., Grosser, R.C., Alegria, m., Bird,H.R., Bourdon, K.H. (1997). Correlates of unmet need for mental services by children and adolescents. Psychol Med 25: 1145-1154.

[15] Glied S. (1998). Too little time?The recognition and treatment of mental health problems in prim ary care.Health Services Research 33: 891-910.

[16] Gureje O. O., O., Gater, R., Aha, R. A., Ikuesan, B. A., Morris J. (1994).Psychiatric disorders in a pediatric primary care clinic. . British Journal of Psychiatry 165: 527-530.

[17] Hinshaw S. P. (2005). The stigmatization mental illness in children and parents: Developmental issues, family concern and research needs. . Journal of child Psychology and psychiatry 46: 714-734.

[18] Kapungwe A., Cooper, S., Mayeya, J, Mwanza, J. (2011. Mental Health and poverty project research program consortium. Attitude of primary health care provider towards people with mental illness: evidence from two districts in Zambia. African journal of psychiatry (Johannesburg) 14: 290-297.

[19] Kieling C., (2010). Global mental health 2. Child and adolescent mental health worldwide: evidence of action. The lancet series S0140-6736: 6827-6821;6820-6830.

[20] Kilian R., Losert, C., Park, A., McDaid, D., Knapp M. (2010). Cost-effectiveness analysis in child and adolescent mental health problems: an updated review of literature. Int J Ment Health Promot. 12: 45-57.

[21] Medina C.O' Kullgren G., Dahlblom K. (2014).A qualitative study on the primary healthcare professionals' perceptions of mental health, suicidal problems and help seeking among young people in Nicaragua.BMC Family Practice, 15:129.doi:10.1186/1471-2296-15-129

[22] Ndetei D. M., Khasakhala L.I., Mutiso, V., Mbwayo, A.W. (2011). Knowledge, attitude and practices (KAP) on mental illness among staffs in general medical facilities in Kenya: practices and policy implication. African journal of psychiatry 14: 225-235.

[23] Nyati Z., Sebit, MB.(2002). Burden of mental illness on family members, care-givers and the community.East Afr Med J 79: 206-209.

[24] Omigbodun O. (2004). Psychological issues in child and adolescent psychiatric clinic population in Nigeria. SocPsychiatrEpidemiol 39: 667-672.

[25] Urada D., Schaper E., Alvarez L., Reilly C., Dawar M., Field R., Antonni V., Oeser B.,CrèvecoeurMacPhailD., Rawson R.A. (2012). Perceptions of Mental Health and Substance use Disorder Services Integration among the Workforce in Primary Care Settings. Vol 44, Issue 4: 292-298.

[26] World health Organization (2001).Mental health; new understanding new hope.The W.H.O report.Geneva Switzerland.

[27] World Health Organization (2003).Caring for children and adolescent with mental disorders. World Health Organization W. H.O Geneva.

[28] Patel V., Flisher, AJ.,Hetrick, S., McGorry, P. (2007). Mental health of young people: a global publichealth challenge. Lancet 369: 1302-1313.

[29] Patel V., Flisher, AJ.,Nikapota, A., Malhotra, S., (2008). Promoting child and adolescent mental health in low and middle income countries.J Child Psychol Psychiatry 49: 313-334.

[30] Patel V., Kieling, C., Pallab K., Maulik, Gauri, D. (2013). Improving access to care for children with mental disorders: A Global Perspective.Arch Dis Child 98: 323-327.

[31] Paula C., Nakamura, E., Wissow, L., Bordin, I .A.,Nascimento. R., Leite, A., Cunha, A., Martin, D. (2009). Primary care and children's mental health in Brazil.AcadPediatr9: 249-255.

[32] Prince M., Patel, V., Saxena, S. 2007. No health without mental health. Lancet. 370: 859-877.

[33] Saxena S., Thornicroft, G., Knapp, M., Whiteford, H. (2007). Resources for mental health: scarcity, inequity, and inefficiency. Lancet 370: 878-889.

[34] Sharan P., Sagar, R. (2007). Mental health policy for children and adolescents in developing countries.J Indian Assoc Child Adolesc Mental Health 3: 1-4.

[35] Singh S., Kamal, P. (1981). Drug abuse among school and college students in Punjab.Child Psychiatry $Q$ 14: 5-11.

[36] Tadesse, B., kebede, DT., and Alem, A., (1999). Childhood behavioral disorders in Ambo district western Ethiopia. Prevalence estimate.ActaPsychiatrScandSuppl, 397: 92-97.

[37] Theiler, AA. (2011). Primary care providers' perception of mental and behavioral health problems in frontier areas of Idaho. Master of Health Science, General Research.Idaho, Boise State University.

[38] US Department of Health and Human Services. (1999). Mental Health: A Report of the Surgeon General Rockville, MD. 
[39] Wang P., Berglund, P., Olfson, M., Pincus, HA., Wells, KB., Kessler, RC. (2005). Failure and delay in initial treatment contact after first onset of mental disorders in the National Comorbidity Survey Replication. Arch Gen Psychiat. 62: 603-613.

[40] Zechmeister, I., Kilian, R., McDaid, D. (2008). Is it worth investing in mental health promotion and prevention of mental illness? A systematic review of the evidence from economic evaluations. BMC Public Health 8: 20. 